\title{
Edukasi Penggunaan Gadget Terhadap Perkembangan Sosial, Emosional Pada Anak Usia Dini
}

\author{
Ester Lina Situmorang ${ }^{1}$, Daniel Agustin ${ }^{2}$, Rikardo Dayanto Butar- \\ Butar $^{3}$, Yuliati Siantajani ${ }^{4}$, Lidya Dewi $S^{5}$, Florence Telaumbanua ${ }^{6}$, \\ Rohdamai Yanti Waruwu ${ }^{7}$ \\ 1, 2, ${ }^{3}$ Prodi Teologi, STT Real Batam \\ 4, 5, 6,7 Prodi PK-AUD, STT Real Batam \\ *linae440@gmail.com
}

\begin{abstract}
The use of gadgets in early childhood has the potential to trigger social emotional development disorders by showing symptoms such as the inability to get along with peers and the surrounding environment, children are unable to recognize their own emotions and those of others, children are also unable to communicate and interact with the surrounding environment. This study uses a qualitative method by analyzing various journals, books, and information about the socio-emotional development of early childhood, identifying indicators, urgency in early childhood social-emotional development so as to achieve the socio-emotional development of children who are able to socialize and and behave to understand oneself and others. The results show 1). The use of gadgets can hinder the social-emotional development of early childhood. 2) The socio-emotional development of children really needs to be taught by parents or PAUD educators to help children develop in designing a better life .3). The urgency of socio-emotional development makes early childhood ready to face the needs of themselves and the surrounding environment.
\end{abstract}

Keywords:Education, Gadget Use, Social Development, Emotional, Early Childhood

\begin{abstract}
Abstrak
Penggunaan gadget pada anak usia dini berpotensi memicu gangguan perkembangan sosial emosional dengan menunjukkan gejala - gejala seperti ketidakmampuan bergaul dengan teman sebayanya dan lingkungan sekitar, anak tidak mampu mengenali emosi dirnya sendiri dan orang lain, anak juga tidak mampu berkomunikasi dan berinteraksi dengan lingkungan sekitarnya. Penelitian ini menggunakan metode kualitatif dengan mengalisis berbagai Jurnal, buku- buku, dan informasiinformasi tentang perkembangan sosial-emosional anak usia dini, mengindentifasi indakator, urgensi dalam perkembangan sosial emosinal anak usia dini sehingga mencapai pengembangan sosialemosial anak yang mampu bersosialisasi dan dan berprilaku memahami diri sendiri serta orang lain.Hasil penelitian menunjukkan1).Penggunaan gadget dapat menghambat perkembangan sosialemosial anak usia dini.2) Perkembangan sosial-emosional anak sangat perlu diajarkan oleh orangtua atau pendidik PAUD untuk membantu perkembangan anak dalam mendesain kehidupan yang lebih baik.3). Urgensi perkembangan sosial emosional menjadikan anak usia dini siap menghadapi kebutuhan dirinya sendiri dan lingkungan sekitarnya.

Kata kunci: Edukasi, Penggunaan Gadget, Perkembangan Sosial, Emosional, Anak Usia Dini
\end{abstract}

\section{PENDAHULUAN}

Teknologi dan globalisasi telah mengubah secara signifikan cara hidup dan bekerja saat ini, termasuk penggunaan gadget. Gadget adalah perangkat elektronik yang memiliki fungsi yaitu fungsi dan penerapan unsur-unsur inovasi, dari hari ke hari, dan juga membuat hidup seseorang menjadi lebih nyaman ${ }^{1}$. Di era digital, penggunaan gadget sangat sulit dihindari, tuntutan perkembangan zaman mendorong orangtua mengenalkan teknologi sejak usia dini, anak- anak tentu sangat senang jika memperoleh gadget dari orang tua mereka Namun, menggunakan gadget tanpa pembatasan dan

\footnotetext{
${ }^{1}$ Sucipto \& Nuril Huda, "Pola Bermain Anak Usia Dini Di Era Gadget Siswa Paud Mutiara Bunda
} Sukodono Sidoarjo," Jurnal Ilmiah"Fonema" Volume 3 N (2016): 225-275. 
pengawasan orangtua akan menyebabkan gangguan terhadap perkembangan sosial- emosional anak usia. Hal ini dapat dilihat dari Indikator anak usia dini yang perkembangan sosialnya yang rendah, antara lain: ${ }^{2}$ Tidak suka berbaur atau bermain dengan anak - anak lainya, lebih suka menyendiri, mengambil mainan teman sesuka hati, bertengkar dan berkelahi sesama teman, tidak suka bergiliran, tidak suka berbagi, sangat posesif (menonjolkan kepemilikan) akan mainannya, menjadi agresif dan berteriak teriak ketika ia tidak mendapatkan yang ia inginkan. Dalam Penelitan Sucipto dan Huda (2016) menuliskan bahwa anak yang suka menggunakan gadget akan suka menyendiri dan kurang berinteraksi dengan lingkungan sekitar sedangkan untuk usia dini proses interaksi sangat berperan penting dalam perkembangan soial-emosial. Daniel Goleman mengungkapkan bahwa banyak orang secara intelektual tinggi malah menjadi bawahan orang yang memiliki intelektual rendah. Menurutnya, para pemimpin yang memiliki kecerdasan intelektual rendah, memiliki perkembangan emosional yang tinggi. Perkembangan emosionalnya ditunjukkan dengan kapasitasnya untuk berempati dengan orang lain, memahami petunjuk - petunjuk, menunjukkan kegigihan dan ambisi pribadi. Disisi lain, orang yang memiliki kecerdasan intelektual tinggi mengalami kesulitan bergaul dengan orang lain, kurang memahami diri sendiri, memiliki masalah dengan kendali dorongan hati, atau tuna emosi (yaitu kesulitan mengidentifikasi apa yang dirasakan pada suatu saat). Mereka kemungkinannya lebih besar untuk mengalami kesulitan dalam hidup walaupun disekolah mereka memiliki prestasi akademik cemerlang. ${ }^{3}$

Berdasarkan latar belakang masalah penulis menemukan pertama, bahwa penggunaan gadget terhadap anak usia dini akan dikwatirkan mengganggu sosial- emosional anak, dimana anak seharusnya bisa didik dengan baik bagaimana berinteraksi dengan teman - teman sebayanya, maupun dengan lingkungan sekitar. Anak juga akan mengalami gangguan emosional dan berprilaku seperti mudah marah ketika tidak diberi kesempatan untuk bermain gadget. Permasalahan ini didukung oleh penelitian dalam jurnal Novianti \& Garzia $(2020)^{4} \quad$ Kedua, anak akan kurang berinteraksi sosial dengan teman- teman sebayanya dan lingkungan sekitar, karena sudah senang dengan bermain gadget ${ }^{5}$.Ketiga, anak malas bergerak dan beraktifitas, karena setiap waktunya digunakan untuk akses gadget, anak akan lupa waktu seperti makan, tidur, belajar.masalah ini diperkuat dalam jurnal Nurul dan Wahyu (2016) ${ }^{6}$. Lambat laun anak lebih memilih dan menyukai duduk dengan tenang di depan gadget dan mengakses yang ada didalam gadget tersebut. Tujuan penelitian ini adalah pertama untuk mengidentifikasi penggunaan gadget terhadap perkembangan sosial-emosional pada anak usia dini. Kedua untuk mengetahui optimal atau tidakkah perkembangan sosial-emosional bagi anak usia dini. Ketiga untuk menemukan urgensi perkembangan sosial-emosional bagi anak usia dini. Pertanyaan pertanyaan ini akan dijawab dalam tulisan ini.

\section{Metode Penelitian}

Kegiatan Edukasi ini dilaksanakan di GBI Masyeba Batu Aji pada tanggal 7 Februari 2021 dengan target jangkauan 30 orang Anak Usia Dini. Untuk melakukan kegiatan pengabdian ini maka tahapan yang dilakukan yaitu:

1) Observasi. Tahap ini dilakukan untuk mengenal kondisi kelompok masyarakat sasaran untuk kegiatan pengabdian agar pelaksanaan program dapat terencanakan secara baik dan efesien. "perencanaan adalah hal memilih dan menghubungkan fakta-fakta serta hal membuat dan menggunakan duga-dugaan mengenai masa yang akan datang dalam hal menggambarkan dan merumuskan kegiatan-kegiatan yang akan dilaksanakan yang dianggap perlu untuk mencapai hasilhasil yang diinginkan. ${ }^{7}$ observasi ini dilakukan agar edukasi yang dilakukan dapat tepat sasaran dan

${ }^{2}$ Wiyani Ardy Novan, Mengelola\& Mengembangkan Kecerdasan Sosial \& Emosi Anak Usia Dini, ed.

Rose KR, 1st ed. (Yogyakarta: AR-RUZZ MEDIA, 2014).

${ }^{3}$ Thomas Armstrong, Kecerdasan Multipel Di Dalam Kelas (Jakarta: Indeks, 2013).

${ }^{4}$ Novianti Ria;Garzia Meyke, "Penggunaan Gadget Pada Anak Usia Dini;Tantangan Baru Orang Tua

Milenial,” Jurnal Obsesi: Jurnal Pendidikan Anak Usia Dini Volume 4, no. 2 (2020): 1000-1010.

${ }^{5}$ Pebriana Hana Putri, "Analisis Penggunaan Gadget Terhadap Kemampuan Interaksi Sosial Pada Anak

Usia Dini,” Jurnal Obsesi: Jurnal Pendidikan Anak Usia Dini 1, no. 1 (2017): 1-11.

${ }^{6}$ Novitasari Wahyu;Khotimah Nurul, "Dampak Penggunaan Gadget Terhadap Interaksi Sosial Anak

Usia 5-6 Tahun,” PAUD Teratai 5, no. 3 (2016): 182-186.

${ }^{7}$ Robinson Tarigan M.R.P, Perencanaan Pembangunan Wilayah (Jakarta: Bumi Aksara, 2005).4 
relevan, 2) Persiapan, pada tahap ini tim PkM mempersiapkan berbagai kebutuhan yang diperlukan dalam edukasi seperti bahan edukasi, power poin, Tim IT, dan Ruangan, 3) Seminar, di tahap ini Tim PkM yang terdiri dari dosen dan mahasiswa memberikan edukasi kepada Anak Usia Dini untuk yang berjemaat di GBI Masyeba batu Aji, 4) Laporan kegiatan, pada tahap ini Tim PkM membuat laporan kegiatan edukasi untuk keperluan publikasi di Jurnal PkM STT Real Batam sebagai sarana aktualisasi ilmu dan pengetahuan. Langkah-langkah penelitian yang akan dilaksanakan melalui observasi. Observasi adalah cara dan teknik pengumpulan data dengan melakukan pengamatan dan pencatatan secara sistematis terhadap gejala atau fenomena yang ada pada proyek penelitian. ${ }^{8}$

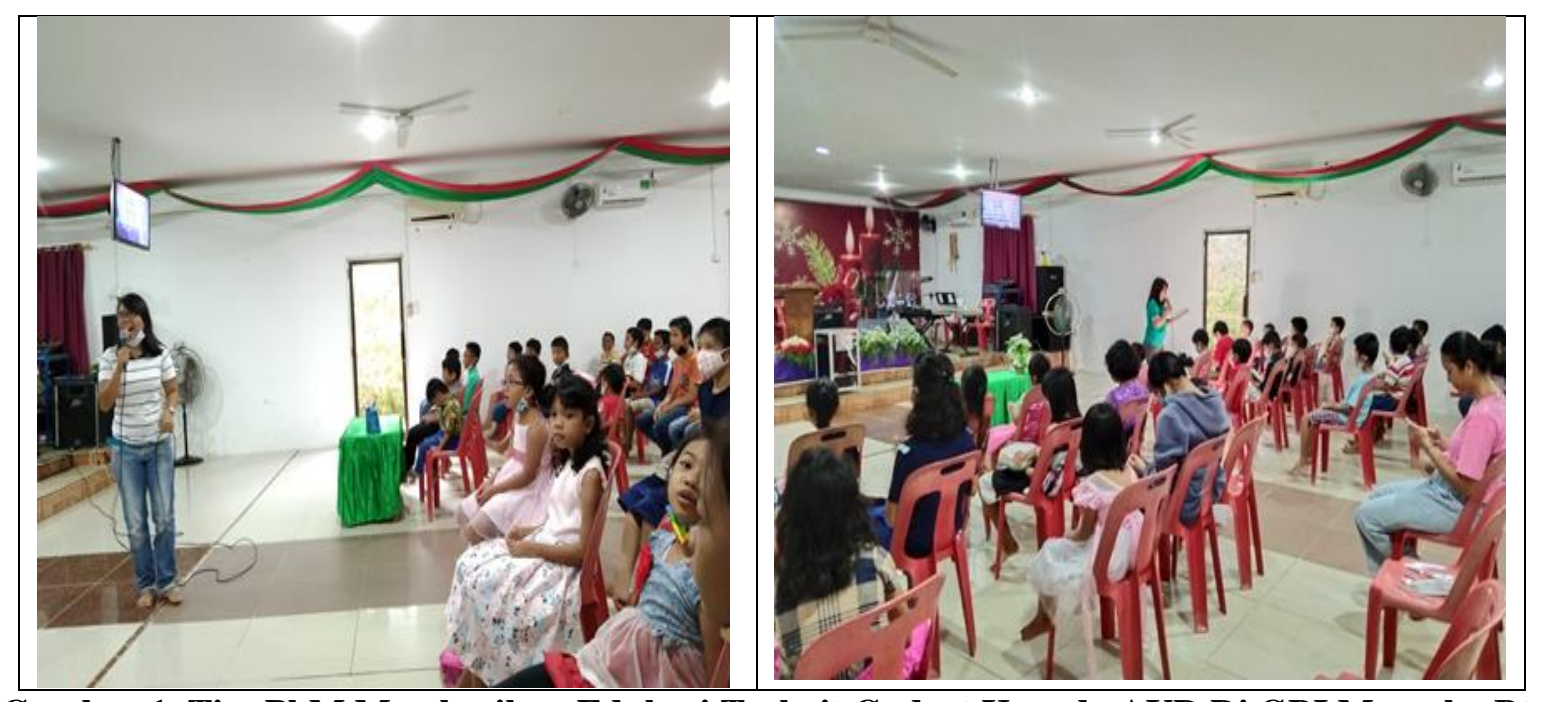

Gambar 1. Tim PkM Memberikan Edukasi Terkait Gadget Kepada AUD Di GBI Masyeba Bt. Aji Batam

\section{HASIL PEMBAHASAN Penggunaan Gadget}

Gadget adalah istilah yang berasal dari bahasa Inggris, yaitu sebuah alat elektronik kecil yang memiliki tujuan dan fungsi tertentu sesuai dengan informasi terkini dan teknologi serta fungsi terkini, membuat hidup seseorang menjadi lebih nyaman. Program-program ini tersedia melalui Internet dengan komputer atau laptop, tablet, video game dan sebagai ponsel atau smartphone Gadget juga merupakan perangkat elektronik, terutama dalam pekerjaan manusia9. Dulu hanya di tangan orang, terutama orang dewasa, sekarang baik remaja maupun anak-anak bisa menggunakan gadget. Gadget, pertama-tama hanya dapat dibeli oleh mereka yang memiliki banyak uang, tetapi pada masa kini orang-orang dengan pendapatan rendah gadget dapat dibeli dengan harga lebih murah atau menggunakan sistem pembayaran kredit. Selain itu, sering disadari bahwa banyak produsen gadget memiliki sasaran anak-anak. gadget modern sangat populer di kalangan anak muda. Karena gadget modern sangat berbeda dari yang dulu, yang hanya menghubungkan atau mengirim pesan, dan dikombinasikan dengan tampilan yang biasa .Sedangkan pada gadget modern sedang dikembangkan artikel-artikel yang sangat menarik, dengan desain yang menarik, dan penggunaan teknologi layar sentuh yang membuatnya lebih atraktif, begitu juga dengan gadget modern yang dipenuhi dengan berbagai macam aplikasi dalam grid. Game saat ini sangat beragam, mulai dari game bertema petualangan, dan pembelajaran. Kemudian, tampilan setiap aplikasi (game) dengan warna dan simbol yang berbeda, dan tidak heran jika gadget ini sangat populer di kalangan anak-anak saat itu. Menyajikan berbagai aplikasi, membuat mereka sangat senang lama - lama di depan gadget, dan itu

\footnotetext{
${ }^{8}$ Pabundu Tika, Metodologi Penelitian Geografi (Jakarta: Bumi Aksara, 2005).12

${ }^{9}$ Pebriana Hana Putri, "Analisis Penggunaan Gadget Terhadap Kemampuan Interaksi Sosial Pada Anak Usia Dini."
} 
tidak baik, akibatnya mereka akan menjadi pribadi yang tidak peduli dengan lingkungannya, baik di dalam keluarga maupun di masyarakat. Sikap acuh tak acuh terhadap keadaan lain seseorang dijaga seminimal mungkin, dan bahkan terasing dari lingkungannya.

\section{Anak Usia Dini}

Pendidikan anak usia dini adalah pendidikan tingkat tinggi pada pendidikan dasar, yang merupakan upaya pembinaan yang ditujukan kepada anak sejak lahir sampai dengan usia enam tahun, yang dilaksanakan dengan memberikan insentif kepada lembaga untuk membantu pertumbuhan dan perkembangan fisik dan mental. agar mereka siap memasuki dunia pendidikan. yang akan dilakukan melalui jalur resmi, informal, informal dan informal ${ }^{10}$.

Pendidikan usia dini juga adalah suatu bentuk pendidikan yang ditujukan untuk meletakkan dasar bagi pertumbuhan dan perkembangan fisik keterampilan dan aktivitas motorik kasar, kecerdasan berpikir, kreativitas, kecerdasan emosional, kecerdasan spiritual, dan sosial-emosional (sikap dan perilaku), dan dalam agama. Bahasa, dan dalam komunikasi, sesuai dengan keunikan dan tahap perkembangan anak usia dini. Pada tahap ini anak akan mengeskplor dan berinteraksi langsung dengan lingkungan sekitarnya, biasanya cenderung senang dengan hal - hal baru yang mereka temukan melalui aktivitas bermain pada masa ini anak bermain dan memuaskan rasa penasaran merela melalui bermain gadget, karena gadget sangat menarik bagi mereka apalagi dengan adanya aplikasi gameonline, sehingga kebanyakan mereka menghabiskan waktu seharian bermain gadget. Tidak bisa dipungkiri bahwa gadget sangat mempengaruhi kehidupan anak, yang seharusnya bermain dan berinteraksi dengan teman-teman sebayanya kini telah digantikan oleh gadget. Ada beberapa fakta yang dapat menunjukkan betapa urgent atau pentingnya PAUD. Pertama, proses pertumbuhan manusia secara utuh sudah diawali semenjak kandungan ibunya sampai usia enam tahun. Anak umur enam tahun ialah fondasi utama dalam pengembangan individu anak, baik yang berkaitan dengan kepribadian, keahlian raga, kognitif, bahasa, seni, sosial emosional, spritual, disiplin diri, konsep diri, ataupun kemandirian ${ }^{11}$. E. Mulyasa mengartikan PAUD merupakan upaya menanamkan akidah serta keimanan, disiplin, pembuatan serta pembiasaan sikap positif, dan pengembangan kemampuan anak. ${ }^{12}$ Sementara itu, dalam Undang - Undang RI Nomor 20 Tahun 2003 pada pasal 1 tentang Sistem Pendidikan Nasional disebutkan bahwa PAUd adalah suatu upaya pembinaan yang ditujukan kepada anak - anak sejak lahir hingga usia enam tahun yang dilakukan melalui pemberian rangsangan pendidikan untuk membantu pertumbuhan dan perkembangan jasmani serta rohaninya agar anak memilki kesiapan dalam memasuki jenjang pendidikan selanjutnya. ${ }^{13}$ Sedangkan, dalam UndangUndang RI No 20 Tahun 2003 pada pasal 1 tentang Sistem Pembelajaran Nasional disebutkan PAUD merupakan upaya pembinaan yang diperuntukkan kepada anak- anak semenjak lahir sampai umur 6 tahun yang dilaksanakan lewat pemberian rangsangan pembelajaran untuk menolong perkembangan dan pertumbuhan jasmani dan rohaninya supaya anak memilki kesiapan masuk ke jenjang pendidikan berikutnya. Perkembangan sosial-emosional anak usia dini terkait dengan kemampuanya dalam berinteraksi dengan orang lain dan mengekspesikan perasaanya terhadap diri sendiri dan orang lain. Seperti manusia dewasa, anak usia dini, termasuk yang masih bayi adalah mahluk sosial. Anak membutuhkan kehadiran orang lain untuk bermain bersama dan bersahabat. Kerjasama dan persahabatan tersebut dijalin dengan bahasa mereka seiring dengan perkembanganya. ${ }^{14}$ Pergaulan anak bersama teman- temanya yang terus bertambah lewat aktivitas bermain baik di sekolah maupun

${ }^{10}$ Widodo Hery, Dinamika Pendidikan Anak Usia Dini, ed. Yuni Winarti (Semarang: Alprin, 2019).

${ }^{11}$ Najib Muhammad;Wiyani Ardy Novan;Sholichin, Strategi Pendidikan Karakter Bagi Anak Usia

Dini, 1st ed. (Yogyakarta: Penerbit Gava Media, 2016).

${ }^{12}$ Mulyasa E., Manajemen PAUD (Bandung: Rosdakarya, 2014).

${ }^{13}$ Imam Musbikin, Buku Pintar PAUD: Tuntutan Lengkap Dan Praktis Para Guru PAUD (Yogyakarta: Laksana, 2010).

${ }^{14}$ Alzena Masykouri, Membangun Sosial Emosi Anak Di Usia 0-2 Tahun (Jakarta: Dirjen PAUDNI, 2011). 
di lingkungan sekitar bisa memampukan anak menguasai dirinya sendiri bertindak kooperatif, toleran, membiasakan diri serta mematuhi ketentuan yang berlaku dirumah, sekolah serta lingkungan sekitar Perkembangan emosi anak usia dini berlangsung secara bersamaan dengan perkembangan sosial anak usia dini. Ada yang beranggapan bahwa perkembangan emosi anak usia dini dipengaruhi oleh perkembangan sosial walaupun perkembangan emosi memberi dampak terhadap perkembangan sosial mereka. Hal itu dikarenakan emosi yang ditampilkan anak usia dini sebenarnya merupakan respon dari hubungan sosial yang ia jalani dengan orang lain, dan emosi tersebut juga akan mempengaruhi keberlanjutan hubungan sosial tersebut. Jadi pada dasarnya ada semacam siklus antara perkembangan sosial dengan perkembangan emosi pada anak usia dini. Najib; Wiyan; Sholichin dalam bukunya menuliskan aspek sosial-emosional anak penting untuk dikembangkan karena alasan:

1. Semakin kompleksnya permasalahn kehidupan disekitar anak, termasuk di dalamnya perkembangan IPTEKS yang banyak memberikan tekanan pada anak dan mempengaruhi perkembangan sosial-emosionalnya.

2. Anak adalah praktisi dan investasi masa depan yang perlu dipersiapkan secara maksimal baik aspek perkembangan sosilanya maupun emosionalnya

3. Rentang usia penting pada anak terbatas, jadi anak harus difasilitasi seoptimal mungkin agartidak ada satu fase pun yang terlewatkan.

4. Ternyata anak tidak bisa hidup hanya mengandalkan kecerdasan intelektual saja, tetapi juga kecerdasan sosial-emosionalnya. ${ }^{15}$

\section{Perkembangan Sosial}

Hakikat perkembangan sosial pada anak usia dini dapat dideskripsikan dengan menjawab satu pertanyaan, yaitu apakah perkembangan sosial anak usia dini itu? Perkembangan digunakan untuk menyatakan sebagai perubahan dalam aspek psikologis atau kejiwaan, seperti aspek kognitif, bahasa, sosial, emosi, moral dan agama. ${ }^{16}$ Kemudian kata sosial berkenaan dengan hubungan antara seorang individu dan individu lainya, dan sebaliknya. Anak usia dini adalah anak yang berumur 0 hingga 6 tahun yang melewati masa bayi, masa batita, dan masa prasekolah. ${ }^{17}$ Berdasarkan deskripsi diatas maka perkembangan sosial anak usia dini dapat didefinisikan dengan berbagai perubahan terkait dengan kemampuan anak usia 0-6 tahun dalam menjalin relasi dengan dirinya sendiri maupun dengan orang lain untuk mendapatkan keinginanya. M. Arifkhoiruddin dalam tulisannya bahwa perkembangan sosial merupakan kemampuan bertindak sesuai dengan tuntutan sosial yaitu terjalinnya hubungan antara anak dengan teman-temannya, yang tumbuh dari tahun ke tahun. Anak-anak tidak hanya bermain dengan anak-anak lain, tetapi juga berbicara. Jika anak dapat membangun hubungan baik dengan orang lain, walaupun hanya kadang-kadang, akan lebih baik dari pada hubungan sosial yang sering terjadi tetapi tidak terjalin dengan baik. Setiap anak yang berinteraksi dengan sesamanya dari pada benda seperti gadget akan lebih mampu mengembangkan kemampuan sosialnya. Dapat dikatakan, kemampuan seorang untuk memenuhi kebutuhan sehari-harinya maupun menyelesaikan tugas-tugas keseharianya sangat lah di tentukan oleh kemampuanya dalam bersosialisasi. Tapi sayangnya, tidak semua anak dapat bersosialisasi dengan optimal. Ada yang dapat bersosialisasi dengan baik, ada pula yang kurang dapat bersosialisasi dengan baik bahkan malah sama sekali tidak bersosialisasi. Ketidakmampuan seorang anak dalam bersosialisasi sudah tentu dipengaruhi oleh perkembangan aspek sosialnya yang terhambat. Ketidakmampuan dalam bersosialisasi bukan hanya dialami oleh orang dewasa, anak usia dini pun mengalaminya. Kini pertanyaanya, jika di usia dini saja anak kurang mampu ataupun tidak memiliki kemampuan untuk bersosialisasi, bagaimana kelak jika

${ }^{15}$ Ali Nugraha dan Yeni Rachmawati, Metode Pengembangan Sosial Emosional (Jakarta: Universitas Terbuka, 2011).

\footnotetext{
${ }^{16}$ Enung Fatimah, Psikologi Perkembangan:Perkembangan Peserta Didik (Bandung: Pustaka Setia, 200AD).

${ }^{17}$ Wiyani Ardy Novan, Mengelola\& Mengembangkan Kecerdasan Sosial \& Emosi Anak Usia Dini.
} 
mereka sudah dewasa? Mereka dituntut untuk dapat hidup bersama dengan orang lain, menyesuaikan, dan saling bekerja sama untuk meraih cita-citanya. Salah satu dampak dari ketidakmampuan anak usia dini dalam bersosialisasi adalah anak usia dini dapat mengalami gangguan perilaku antisosial. Perilaku anti sosial diartikan reaksi menentang orang lain. Pada kehidupan sehari hari, perilaku antisosial pada anak usia dini sangat mudah ditemui, dilingkungan sekolah, Taman kanak - kanak dan Kelompok Bermain

\section{Faktor yang Mempengaruhi Perkembangan Sosial}

Faktor lingkungan sebagai kekuatan yang kompleks dari dunia fisik dan sosial yang memilki pengaruh pengalaman sosial anak sejak sebelum dan sesudah lahir. Faktor lingkungan ini meliputi semua pengaruh lingkungan, termasuk didalamya pengaru- pengaruh berikut: ${ }^{18}$

1. Keluarga

Pada ilmu pendidikan, keluarga menjadi lingkungan pendidikan yang pertama dan utama. Dengan demikian lingkungan keluarga memiliki peran yang utama dalam menemukan perkembangan sosial anak dikemudian hari, dilingkungan keluarga anak pertama kalinya menerima pendidikan. Orangtua mereka merupakan pendidik bagi mereka. Pola asuh orang tua, sikap, serta situasi dan kondisi yang sedang melingkupi orang tua dapat memberikan pengaruh terhadap perkembangan sosial anak usia dini.

\section{Sekolah}

Sekolah merupakan lingkungan kedua bagi anak, di sekolah anak berhubungan dengan pendidik PAUD dan teman sebayanya. Hubungan antara anak dengan pendidik PAUD dan anak dengan teman sebayanya dapat memengaruhi perkembangan sosial anak. Perkembangan sosial dapat dilihat ketika anak melakukan kegiatan bermain dengan teman sebayanya, misalnya, anak menjalin hubungan serta bekerja sama dengan anak lainya dalam suatu permainan.

3. Masyarakat

Secara sederhana, masyarakat diartikan sebagai kumpulan individu atau kelompok yang diikat oleh kesatuan negara, kebudayaan dan agama. Di dalamya termasuk semua jalinan hubungan timbal balik yang berangkat atas kepentingan bersama, adat, kebiasaan, pola - pola, teknik- teknik, sistem hidup, undang - undang, institusi dan semua segi fenomena yang dirangkum oleh masyarakat dalam pengertian luas dan baru. Jadi ada lima unsur yang ada dalam masyarakat, yaitu;

a. Hidup bersama, dua orang atau lebih

b. Hidup bercampur dan bergaul cukup lama

c. Hidup dalam suatu kesatuan yang utuh

d. Mereka sadar bahwa sistem kehidupan bersama menimbulkan sebuah kebudayaan tersendiri sehingga merasa adanya keterikatan diantara mereka

e. Adanya aturan yang jelas dan disepakati bersama.

Budaya, kebiasaan, keadaan demografi pada suatu masyarakat dapat memengaruhi cara belajar dan hasil belajar anak, religiusitas suatu masyarakat juga kan sangat menentukan dalam perkembangan sosial anak.

\section{Ciri - Ciri Perkembangan Sosial Anak Usia Dini}

${ }^{18}$ Rini dkk Hildayani, Psikologi Perkembangan Anak (Jakarta: Universitas Terbuka, 2007). 
Anak usia dini yang memiliki perkembangan sosial akan memiliki kemampuan untuk memahami orang lain, meskipun usianya masih terbilang dini. Perkembangan emosional pada usia dini dapat diamati oleh orangtua maupun Pendidik PAUD ketika sedang bermain dilingkungannya.

Ciri-ciri anak usia dini yang memiliki Perkembangan sosial antara lain:

1. Ia sering menjadi pemimpin bagi teman- temanya dalam kegiatan bermain maupun dalam kegiatan lainya.

2. Ia mempunyai banyak teman di lingkungan sekitar rumah dan lingkungan KB atau TK

3. Ia banyak bersosialisasi di KB ATAU TK dan lingkungan sekitar rumahnya dari pada di dalam rumahnya, meskipun ia memiliki kakak atau adik yang bisa bermain denganya

4. Ia tampak sangat mengenal lingkunagn $\mathrm{KB}$ atau TK dan lingkungan sekita ia tinggal

5. Ia suka bermain secara berkelompok

6. Ia memiliki empati yang besar terhadap orang lain

7. Ia suka mengajari orang lain

Sementara menurut May Lwin dkk, ciri - ciri anak memiliki perkembangan sosial yang tinggi antara lain;

1. Dapat berteman dan berkenalan dengan mudah

2. Senang berada disekitar orang lain

3. Ingin tahu tentang oranglain dan ramah terhadap orang asing

4. Menggunakan mainanya bersama dengan temanya

5. Mau berbagi makanan dengan temannya

6. Mengalah kepada anak - anak lain

7. Mengetahui bagaimana menunggu giliranya selama bermain. ${ }^{19}$

\section{Urgensi Perkembangan Sosial bagi Anak Usia Dini}

Apa yang menjadikan Perkembangan sosial penting atau urgent bagi anak usia dini? Tentunya semua tahu bahwa anak usia dini juga sama seperti orang dewasa. Mereka memiliki keinginan untuk menjalin relasi dengan orang lain untuk memenuhi keinginan ataupun tujuanya. Bahkan perkembangan sosial menjadi dasar bagi anak usia dini dalam beradaptasi dengan lingkungan barunya serta menjalin hubungan dengan teman sebayanya. Dengan demikian manfaat perkembangan sosial bagi anak usia dini antara lain:

1. Anak dapat menjalin komunikasi dengan orang lain

2. Anak mampu beradaptasi dengan orang lain di suatu lingkungan baru

3. Anak mudah tergugah empatinya

4. Anak menjadi sosok yang peduli terhadap sesama

5. Anak mampu menjadi pemimpin bagi dirinya sendiri dan orang lain

6. Anak mau berbagi dengan orang lain

7. Anak bisa dijadikan sebagai tutor sebaya

Betapa penting dan bermanfaat perkembangan sosial bagi anak usia dini. Orangtua pada khususnya serta pendidik PAUD pada umumnya harus mengembangkan aspek sosial pada anak usia dini agar tumbuh dan berkembang perkembangan sosialnya. Jika hal itu dilakukan sejak dini, kedepan anak menjadi sosok yang cenderung berprilaku antisosial.

\section{Perkembangan Emosional}

Sejak bayi, seorang anak sudah menangis, lalu tersenyum tanpa sepenuhnya disadari. Baru setelah si anak bertambah besar, tersenyum dan tertawa ada tujuanya. Arti emosi yang diperlihatkan sejak masa bayi, anak, dan seterusnya mengalami perkembangan dan perubahan. Menurut Yulia Singgih d.

${ }^{19}$ May Lwin dkk, Cara Mengembangkan Berbagai Komponen Kecerdasan, ed. Christine Sujana (Jakarta: Indeks, 2008). 
Gunarsa, Emosional dapat dipandang sebagai: ${ }^{20}$ Pertama, bentuk komunikasi yang memungkinkan bayi dana anak mengungkapkan keterangan mengenai dirinya, perasaan, kebutuhan, dan keinginanya, Misalnya, seorang anak yang tersenyum menandakan bahwa sesuatu menyenangkan dirinya. Kedua, Emosi dapat dipakai sebagai alat pengatur jarak sosial. Misalnya seorang anak menangis minta perhatian orangtuanya. Ketiga, tanda tanda emosional dapat dipakai sebagai fungsi sosial lainya. Misalnya, seorang anak tersentum sebagai tanda senang didatangi ibunya. Keempat, Ekspresi emosional diperlihatkan anak sebagai cara mengatur konflik atau menyatakan kemarahan dengan orang lain. Dengan ungkapan emosional anak menunjukkan kebutuhan dan keinginanya. Anak belajar mengatur orang lain memperlihatkan berbagai macam emosi. Anak juga belajar mengenal dan membaca pesan emosional oranglain. Emosi merupakan suatu cara untuk mengungkapkan kebutuhanya kepada oranglain, mengatur jarak sosial dan komplik. Emosi merupakan salah satu cara yang pertama dipakai untuk mengendalikan dunia dan lingkungan sosial, termasuk orang sekelilingnya. Perkembangan emosional berkenaan dengan hati dan kepedulian antarsesama, manusia, mahluk lain, dan alam sekitar dalam mengelola perasaan nya saat ia berhubungan dengan dirinya sendiri, sesamanya, dan mahluk lain di lingkungannya.

Emosional pada seorang individu harus harus ditumbuh kembangkan sejak berada pada usia dini. Orang tua ataupun Pendidik PAUD perlu menyiapkan anak - anak nya untuk mencapai perkembangan emosianal pada kadar yang tinggi. Hal ini dikarenakan perkembangan emosional pada seorang anak tidaklah berkembang secara alamiah. Ini berarti, seseorang tidak dengan sendirinya memiliki kematangan dalam hal perkembangan emosional semata - mata didasarkan pada perkembangan biologisnya. Sebaliknya perkembangan emosional sangat tergantung pada proses pelatihan dan pendidikan yang dilakukan sejak usia dini secara berkelanjutan hingga dewasa. Disini orangtua atau pendidik PAUD mengambil peranan yang penting memupuk perkembangan emosional anak usia dini. $^{21}$

\section{Kompenen Perkembangan Emosional Anak Usia Dini}

Ada 4 yang harus ditumbuhkembangkan pada anak usia dini agar memiliki perkembangan emosional. Keempat komponen tersebut antara lain. ${ }^{22}$

1. Kemampuan Mengenali Emosi Diri Sendiri

Kemampuan mengenali emosi diri adalah kesadaran diri dalam mengenali perasaan- perasaanya sewaktu itu terjadi dari waktu ke waktu dalam kehidupanya. Kesadaran diri tersebut pada dasarnya merupakan kemampuan untuk mengenal dan memilah- milah perasaan. Memahami hal - hal yang sedang dirasakan, mengapa hal itu dirasakan, dan mengetahui penyebab munculnya persaan tersebut. Pada usia 0-6 bulan, bayi mulai dapat membedakan ekspresi wajah, seperti gembira, marah, dan sedih. Pada usia 7-12 bulan, pengenalan anak terhadap emosi primer meningkat seperti marah, takut, dan sedih. Pada usia 1-3 tahun pengenalan anak terhadap emosi sekunder seperti malu, benci, bingung dan lainya. Kemudian pada usia 3-6tahun, anak usia dini mulai bisa mengenali penyebab munculnya suatu perasaan dan konsekuensi dari munculnya perasaan tersebut.

\section{Kemampuan Mengatur Emosi Diri Sendiri}

Kemampuan mengatur emosi diri sendiri merupakan kemampuan untuk menangani perasaan agar perasaan dapat terungkap dengan pas., kemampuan untuk menghibur diri sendiri, melepaskan kecemasan, kemurungan atau ketersinggungan dan berbagai akibat yang muncul dari berbagai emosi yang negatif. Kemampuan mengatur emosi diri pada anak usia dini mulai muncul di usia 7-12 bulan. Hal itu ditunjukkan dengan respons bayi dalam bnetuk mengoyangkan dirinya, mengunyah objek, atau menghindar dari stimulus yang tidak menyenangkan. Pada usia1-3 tahun kemampuan mengatur emosi

\footnotetext{
${ }^{20}$ Gunarsa D Singgih Yulia, Asas-Asas Psikologi Keluarga Idaman, ed. Sari M awarni Manurung Nino Oktorino, Cetakan ke. (Jakarta: PT BPK GUNUNG MULIA, 2012).

${ }^{21}$ Suharsono, Melejitkan IQ, IE, Dan IS (Jakarta: Inisiasi Press, 2002).

${ }^{22}$ Novan Ardy Wiyani, Pendidikan Karakter Berbasis Iman Dan Taqwa (Yogyakarta: Teras, 2012).
} 
diri meningkat pada saat anak mencoba untuk mengalihkan dirinya sebagai usaha untuk mengontrol stimulus yang membingungkan dirinya. Kemudian pada usia 3-6 tahun mulai muncul pada diri anak perbaikan strategi kognitif untuk mengatur emosinya. Hal itu bisa dilakukan karena pada usia tersebut anak sudah mulai mengenali penyebab munculnya suatu perasaan dan konsekuensi dari munculnya perasaan tersebut. ${ }^{23}$

\section{Kemampuan Mengenali Emosi Orang Lain}

Kemampuan mengenali emosi orang lain disebut empati, yaitu kemampuan memahami perasaan oranglain serta mengomunikasikan pemahaman tersebut kepada orang yang bersangkutan. Kemampuan ini dibangun atas dasar kesadaran diri sendiri, yaitu bahwa orang lain juga memiliki kepentingan seperti halnya dirinya sendiri, sadar bahwa lingkungan yang membentuk individu itu berbeda- beda dan menyadari bahwa tidak ada manusia yang sama, serta perbedaan itu bukan sesuatu yang harus disikapi dengan perlawanan. Semakin seorang individu terbuka dengan dirinya sendiri. Semakin ia mampu mengenali dan mengikuti emosinya, dan semakin mudah pula ia mengenali emosi orang lain. Dengan pembentukan emosi dan pengenalan emosi pada dirinya dan oranglain, anak dapat belajar mengatur orang lain dengan membentuk emosinya. Hasil penelitian menyatakan bahwa anak dapat terikat dengan lebih dari seorang. Para ayah dapat berperan sebagai ayah yang interaktif, teman main, sementara ibu lebih berperan secagai caregiver dan comforter, sebagai pemberi kasih sayang, yang mengurus serta memenuhi kebutuhan anak. Anak dapat terikat pada oranglain, memperlihatkan perasaan sayang pada mereka yang memperhatikanya. Anak - anak yang mengalami rasa sayang dan memiliki keterikatan yang aman, akan mempunyai harga diri tinggi, memiliki rasa ingin tahu dan ingin menyelidiki hubungan sosial yang positif dengan teman sebaya dan lingkungan. Anak usia dini mulai mampu mengenali emosi orang lain sejak bayi. Ketika bayi, ia berinteraksi dengan ibunya. Ibu menjadi model bagi bayi dalam mengenali dan mempelajari emosi orang lain. Jadi, dapatlah dikatakan bahwa orangtua memiliki peranan yang sangat penting dalam mengenalkan emosi orang lain terhadap anaknya. Anak juga akan membutuhkan bimbingan dari orang tua dalam mengenali emosi orang lain. Kemampuan empati anak muncul pada saat berusia 2 tahun. Kemampuan tersebut semakin maksimal bila anak mempunyai kemampuan untuk mengetahui emosional orang lain, mengerti jika orang lain tidak sama dengan dirinya, dan akan belajar mengerti posisi dan pemikiran orang lain. Kemampuan empati anak berkembang maksimal usia -5 tahun. Usia tersebut anak mengembangkan pemahaman semakin mantap terhadap perasaa emosi orang lain seiring dengan kemampuan kognitif yang $\operatorname{dimiliki~}^{24}$

\section{Kemampuan Mengelola Emosi Orang Lain}

Kemampuan mengelola emosi orang lain dapat membantu individu dalam menjalin hubungan dengan orang lain secara terbuka sehingga disukai oleh lingkungannya karena ia menyenangkan secara emosional. Kemampuan mengelola emosi orang lain ini sangat dipengaruhi oleh kecerdasan intrapersonal dan interpersonal yang dimilikinya. Pada usia 0-1 tahun mulai tumbuh perasaan pada anak bahwa ia merupakan seorang pribadi. Baru pada usia1-2 tahun mulai tumbuh kemampuan pada diri anak untuk mengenal dan menjalin hubungan dengan orang lain. Kemudian pada usia 3-6 tahun, anak mulai bisa mengatur dirinya sendiri dalam berhubungan dengan orang lain. Hal itu mengindikasikan bahwa pada usia itu anak mulai dapat mengelola emosi orang lain.

\section{Urgensi Perkembangan Emosional Bagi Anak Usia Dini}

Menurut Daniel Goleman, kecerdasan emosional jauh lebih berperan daripada kecerdasan intelektual dalam menentukan siapa yang akan menjadi bintang dalam pekerjaan- pekerjaan apa pun. Dengan demikian, perkembangan emosional memiliki pengaruh yang tergolong besar dalam

\footnotetext{
${ }^{23}$ Aliah B, Psikologi Perkembangan Islami: Menyingkap Rentan Kehidupan Manusia Dari Perkelahian Hingga Pascakematian (Jakarta: Rajawali Press, 2006).

${ }^{24}$ Ibid.
} 
menunjang kesuksesan hidup seseorang. Jadi, sudah sewajarnya jika orangtua perlu menyiapkan anakanaknya sejak usia dini untuk mencapai perkembangan emosional dengan kadar tinggi.

Urgensi perkembangan emosional bagi anak usia dini antara lain:

1. Perkembangan emosional bagi anak usia dini dapat menjadi alat pengendalian diri agar ia tidak terjerumus ke dalam tindakan-tindakan yang konyol, yang dapat merugikan dirinya sendiri ataupun orang lain dan mahluk lainnya di sekitarnya.

2. Perkembangan emosional bagi anak usia dini dapat dijadikan sebagai alat deteksi bagi orangtua dalam mengenali bakat dan minat anak usia dini.

3. Perkembangan emosional bagi anak usia dini dapat dijadikan modal baginya untuk mengembangkan diri potensinya di lingkungan KB atau TK di lingkungan masyarakat.

4. Perkembangan emosional bagi anak usia dini dapat dijadikan sebagi bekal baginya untuk memupuk jiwa kepemimpinanya dalam bidang apapun.

5. Perkembangan emosional bagi anak usia dini dapat menjadikanya terhindar dari rasa cemas dan takut yang berlebih, kecenderungan menyendiri, rasa gugup, dan minder.

6. Perkembangan emosional bagi anak usia dini dapat dijadikan sebagai penggerak batin dalam berempati dengan orang lain.

Guna mewujudkan anak usia dini yang memiliki perkembangan emosional yang berkadar tinggi, orang tua maupun pendidik PAUD harus mengembangkan emosi anak usia dini. Upaya tersebut dapat dicapai dengan berbagai metode pengembangan emosi anak usia dini.

\section{Gadget Dan Perkembangan Sosial Emosi Anak Usia Dini}

Gadget merupakan alat komunikasi yang memiliki fungsi khusus serta canggih. Sebenarnya gadget memiliki banyak manfaat jika dalam penggunaanya bisa terkontrol dan seimbang, manfaat antara lain menambah ilmu pengetahuan, mempermudah komunikasi, dan memperluas jaringan pertemanan. ${ }^{25}$ Dan sebaliknya akan berdampak negatif jika dalam penggunaanya tidak terkontrol dan tidak seimbang. Dampak negatif yang paling banyak disampaikan orangtua a) anak sudah tidak mengenal waktu, karena setiap waktunya selalu digunakan untuk akses gadget, b) Anak sakit mata, karena anak jarang berkedip dan paparan sinar gadget yang cukup kuat, c) anak kehilangan kontrol diri dan kontrol emosi saat dikurangi apalagi dihilangkan waktunya bermain gadget ${ }^{26} . \mathrm{d}$ ) Anak kurang berinteraksi dengan teman atau lingkungan sekitarnya karena lebih senang menggunanakan gadget. Dalam penelitian (Novitasari dkk), Penggunaan gadget pada anak dikatakan "gadget lebih mengasyikkan ketimbang bermain dengan sahabatnya ${ }^{27}$. Begitu juga banyak hasil penelitian yang mengatakan bahwa gadget yang diberikan orangtua kepada anaknya dalah karena keinginan anaknya, dengan tujuan mengenalkan teknologi supaya anaknya tidak bosan. Orang tua yang beranggapan seperti ini berakibat anak akan bersikap selalui ingin menyendiri dan lama kelaman akan lupa berinteraksi sosial dengan teman dan lingkungan sekitarnya. ${ }^{28}$ Karena anak usia dini akan mengasah kemampuannya bersosialisasi dengan melalui lingkungan bukan dengan gadget. Ada juga orang tua memberikan gadget kepada anaknya untuk mengalihkan perhatian anak supaya tidak mengganggu pekerjaan. ${ }^{29}$ Hal ini juga tidak baik bagi perkembangan sosial anak, anak akan sesuka hati mengakses gadget tanpa kontrol dari orang tua.

Prilaku anak usia dini yang perlu diwaspadai terhadap kecanduan gadget:

${ }^{25}$ Badriyah Nurul, Mewaspadai Media Sosial Terhadap Perkembangan Anak Didik (Telaga Ilmu Indocamp, 2002).

26 Jinan Mutoharun, Panen Kecanduan Gadget, ed. Tim Redaksi (Karanganyar: Penerbit Intera; Smart Meda Prima, 2020).

${ }^{27}$ Novitasari Wahyu;Khotimah Nurul, "Dampak Penggunaan Gadget Terhadap Interaksi Sosial Anak Usia 5-6 Tahun.”

${ }^{28}$ Widiati \&Sugiman, "Pengaruh Penggunaan Gadget Terhadap Daya Kembang Anak” (2014).

${ }^{29}$ Ibid. 
1. Kehilangan minat untuk melakukan aktivitas

2. Anak tidak mau berteman dengan teman sebayannya

3. Selalu melawan orangtua jika disuruh berhenti bermain gadget

4. Mudan tersinggung, sensitif dan memiliki mood yang mudah berubah

5. Anak akan menjadi egois dan tidak perduli dengan teman dan lingkunganya

6. Anak suka berbohong dan curi - curi waktu supaya dapat mengakses gadget

Dari Perilaku- perilaku anak tersebut, dapat disimpulkan bahwa penggunaan gadget pada anak usia dini dapat mengurangi interaksi sosialnya dalam kehidupan sehari-hari baik itu dengan orang tuanya, teman sebayanya, maupun dengan masyarakat. Oleh karena itu, sebaiknya orangtua mendampingi anak saat sedang menggunakan gadget, dan peran serta orangtua dalam mendisiplinkan anak sangat diperlukan supaya tidak kecanduan yang mengakibatkan dampak negatif terhadap perkembangan anak khususnya hubugannya dengan kehidupan sosial anak.

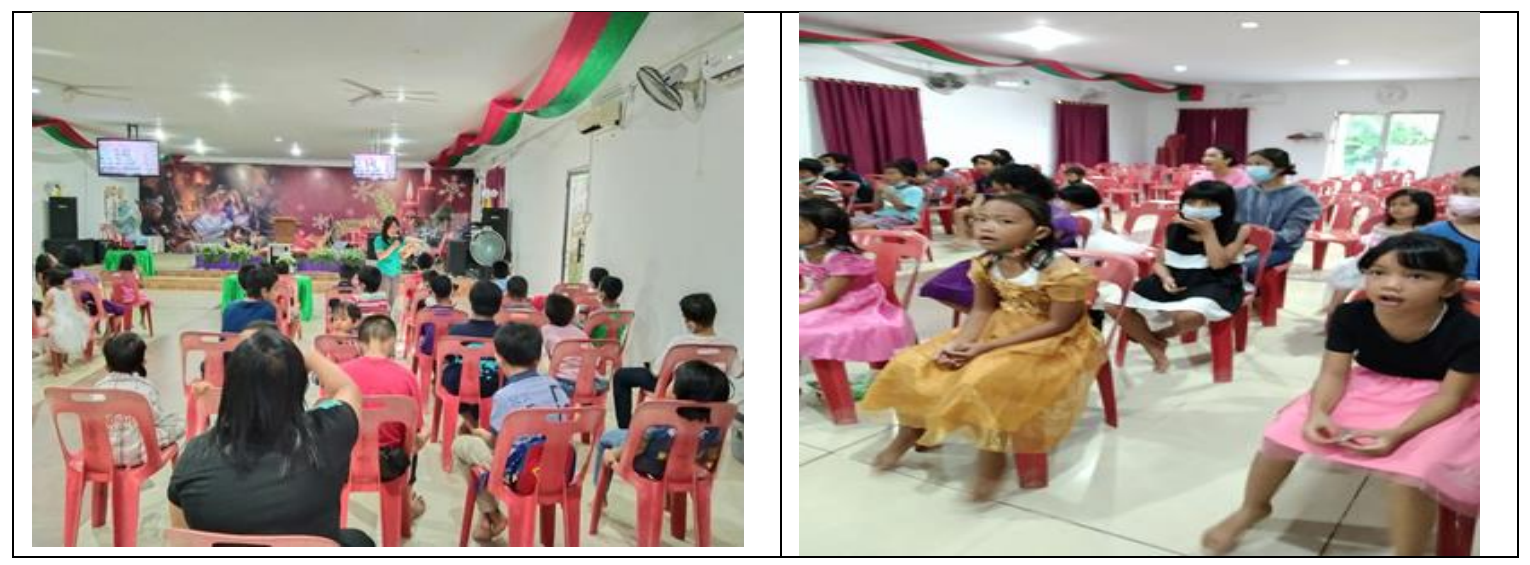

Gambar 1. Anak Usia Dini Mengikuti Edukasi Penggunaan Gadget Di GBI Masyeba Bt. Aji Batam

\section{KESIMPULAN}

Perkembangan Teknologi dan komunikasi yang menghasilkan Gadget yang membawa perubahan besar dalam kehidupan anak usia dini baik secara positif maupun negatif akan mempengaruhi perkembangan sosial-emosional anak usia dini. Tulisan ini menyimpulkan bahwa Penggunaan gadget yang tidak mendapatkan batasan dan perhatian akan merusak perkembangan sosial emosional anak. Dengan adanya Perkembangan sosial-emosional memampukan anak untuk mengembangkan seluruh potensi dalam diri anak berinteraksi dengan teman - teman sebayanya dan lingkungan sekitar serta menolong anak untuk tidak kecanduan dalam mengakses gadget yang membuat mereka nyaman dan lupa berinteraksi dan melakukan segala aktifitas. Dengan perkembangan Emosional juga akan menghasilkan pembentukan emosional yang mampu untuk mengenal dan mengelola emosi yang ada dalam diri anak dan orang lain. Tulisan ini adalah gambaran yang dibutuhkan dalam menolong anak usia dini dalam pertumbuhan dan perkembangan sosial-emosianal sehingga mereka tidak mudah terbawa arus perkembangan zaman yang bisa merusak masa depan anak.

\section{DAFTAR PUSTAKA}

Ali Nugraha dan Yeni Rachmawati. Metode Pengembangan Sosial Emosional. Jakarta: Universitas Terbuka, 2011.

Aliah B. Psikologi Perkembangan Islami: Menyingkap Rentan Kehidupan Manusia Dari Perkelahian Hingga Pascakematian. Jakarta: Rajawali Press, 2006.

Alzena Masykouri. Membangun Sosial Emosi Anak Di Usia 0-2 Tahun. Jakarta: Dirjen PAUDNI, 2011.

Armstrong, Thomas. Kecerdasan Multipel Di Dalam Kelas. Jakarta: Indeks, 2013.

Badriyah Nurul. Mewaspadai Media Sosial Terhadap Perkembangan Anak Didik. Telaga Ilmu Indocamp, 2002. 
Enung Fatimah. Psikologi Perkembangan:Perkembangan Peserta Didik. Bandung: Pustaka Setia, 200AD.

Gunarsa D Singgih Yulia. Asas-Asas Psikologi Keluarga Idaman. Edited by Sari M awarni Manurung

Nino Oktorino. Cetakan ke. Jakarta: PT BPK GUNUNG MULIA, 2012.

Hildayani, Rini dkk. Psikologi Perkembangan Anak. Jakarta: Universitas Terbuka, 2007.

Imam Musbikin. Buku Pintar PAUD: Tuntutan Lengkap Dan Praktis Para Guru PAUD. Yogyakarta: Laksana, 2010.

Jinan Mutoharun. Panen Kecanduan Gadget. Edited by Tim Redaksi. Karanganyar: Penerbit Intera; Smart Meda Prima, 2020.

M.R.P, Robinson Tarigan. Perencanaan Pembangunan Wilayah. Jakarta: Bumi Aksara, 2005.

May Lwin dkk. Cara Mengembangkan Berbagai Komponen Kecerdasan. Edited by Christine Sujana. Jakarta: Indeks, 2008.

Mulyasa E. Manajemen PAUD. Bandung: Rosdakarya, 2014.

Najib Muhammad;Wiyani Ardy Novan;Sholichin. Strategi Pendidikan Karakter Bagi Anak Usia Dini. 1st ed. Yogyakarta: Penerbit Gava Media, 2016.

Novianti Ria;Garzia Meyke. "Penggunaan Gadget Pada Anak Usia Dini;Tantangan Baru Orang Tua Milenial." Jurnal Obsesi: Jurnal Pendidikan Anak Usia Dini Volume 4, no. 2 (2020): 10001010.

Novitasari Wahyu;Khotimah Nurul. "Dampak Penggunaan Gadget Terhadap Interaksi Sosial Anak Usia 5-6 Tahun." PAUD Teratai 5, no. 3 (2016): 182-186.

Pebriana Hana Putri. "Analisis Penggunaan Gadget Terhadap Kemampuan Interaksi Sosial Pada Anak Usia Dini.” Jurnal Obsesi: Jurnal Pendidikan Anak Usia Dini 1, no. 1 (2017): 1-11.

Sucipto \& Nuril Huda. "Pola Bermain Anak Usia Dini Di Era Gadget Siswa Paud Mutiara Bunda Sukodono Sidoarjo." Jurnal Ilmiah"Fonema" Volume 3 N (2016): 225-275.

Suharsono. Melejitkan IQ, IE, Dan IS. Jakarta: Inisiasi Press, 2002.

Tika, Pabundu. Metodologi Penelitian Geografi. Jakarta: Bumi Aksara, 2005.

Widiati \&Sugiman. "Pengaruh Penggunaan Gadget Terhadap Daya Kembang Anak" (2014).

Widodo Hery. Dinamika Pendidikan Anak Usia Dini. Edited by Yuni Winarti. Semarang: Alprin, 2019.

Wiyani Ardy Novan. Mengelola\& Mengembangkan Kecerdasan Sosial \& Emosi Anak Usia Dini. Edited by Rose KR. 1st ed. Yogyakarta: AR-RUZZ MEDIA, 2014.

Wiyani, Novan Ardy. Pendidikan Karakter Berbasis Iman Dan Taqwa. Yogyakarta: Teras, 2012. 